\title{
On the Cultivation of Students' English Autonomous Learning Ability in Vocational Colleges in Leshan City, Sichuan, China
}

\author{
Li Zou \\ School of Foreign Language, Leshan Normal University, China
}

\begin{abstract}
Autonomous learning plays a more and more important role in vocational colleges, especially in terms of English study. Only when the students master autonomous learning ability can they really learn actively in their whole life. Nevertheless, most students in vocational colleges lack this ability, which is caused not only by students' lack of motivation, lack of proper learning strategies but also by teachers' inappropriate teaching approaches as well as by the imperfect educational system. In order to cultivate the students' autonomous learning ability, the writer carried out a research in Leshan Vocational and Technical College, analyzing the causes of the current situation and putting forward some suggestions to the students, the teachers and the educational departments.
\end{abstract}

Index Terms - cultivation, English autonomous learning ability, Vocational Colleges

\section{INTRODUCTION}

It is undoubted that English is the most widely used language in the world. In order to communicate better with the world, China needs a lot of people who master a good command of English. Therefore, currently more and more Chinese students spend more and more time in English study. And most of them depend on schools or training centers to learn English. Although school education and teachers' instruction are very vital to English learning, no one can learn everything in the classroom or the training centers due to the limited time and energy. Most of the job needs to be done by the language themselves on their own. Especially for college students who have more spare time and comparatively less time with teachers, it is necessary for them to grasp the ability of English autonomous learning which is a useful skill to get new knowledge and latest information. This paper is mainly concerned with how to foster English autonomous learning ability of vocational colleges students based on a study carried out in Leshan Vocational and Technical College. And hopefully, this paper is also beneficial to teachers of English and the educational departments.

\section{Previous Studies Of Autonomous LeARning}

According to the previous studies abroad, the definitions of autonomous learning are various. Among so many definitions, the one raised by Holec (1981) is worth mentioning: that is "the ability or capacity or to take charge of one's learning". Many researchers see eye to eye with Holec in the term of autonomous learning as an ability. What is more, according to Holec, the autonomous learners are capable of deciding their goals and aims and then try their best to find opportunities to achieve them.

And Huttunen (1986) put more emphasis on performance in stead of ability. He held that the performance of learning is more important. Furthermore, according to the definition put forward by Littlewood (1996), autonomous learners are "those who master an independent ability to make and accomplish the choices that govern their learning."

In addition, since the 1980s, domestic educators and scholars embarked on different researches on English autonomous learning, including not only theoretical studies but also case studies of English learners' autonomous learning, mostly in colleges and universities. To name just a few, Xie Fang (2002) studied on the importance of cultivating a good habit of autonomous learning in the term of foreign language education in the colleges and universities. Wei Yuyan (2002) put forward the necessity of promoting English learner's autonomous learning. Peng Jinding (2002) carried out the case study to verify that the teaching approach she adopted was positive to cultivating language learners' autonomous learning.

According to the previous studies, the following are the main characteristics of autonomous learning:

First of all, autonomous learning is spontaneous. Traditional learning is decided by exterior conditions such as the school, the teachers and the supervision of parents, etc. In this way, the students' learning is more or less passive. But on the other hand, autonomous learners choose study out of their own needs such as interests, passion, desire to be recognized, dream, etc. The outside effect on them is negligible. As a matter of fact, the autonomous learning is active.

Secondly, autonomous learning is free. Traditional learning is stereotype in which learners can not choose what to learn, when to learn and how to learn. All of the study is decided by schools and teachers who make the plans for students to finish. But on the other hand, autonomous learners are free to choose time, place, resources, process, and 
approaches of the learning, without affected by others. Therefore, the autonomous learners have a clearer goal.

And finally, autonomous learners are self-disciplined. Traditional learners rely too much on exterior environment in that their learning is carried out under the organization of schools and teachers. If the exterior environment changes, the learning will be definitely affected. But on the other hand, autonomous learners play multiple roles in their learning, such as deciders of goal, plan makers, and process managers, etc. In this case, autonomous learning is rarely affected by outside environment and autonomous learners are able to adjust and control their study behavior.

\section{RESEARCH DESIGN}

\section{Research Subjects}

Geographically, Leshan Vocational and Technical College is located closely to Leshan Normal University where the writer works. Therefore, the writer can carry out the study easily. The writer chose 150 non-English majors at their first year in Leshan Vocational and Technical College at random from the department of Finance, Medicine, Hotel Management, Accounting, as well as Computer. Specifically, the 150 research subjects are composed of 100 female students and 50 male students. During the process of the research, the writer will invite their teachers of English to do the favor of handing out and recollecting questionnaires.

\section{Research Questions}

The research questions about English autonomous learning ability mastered by students in Leshan Vocational and Technical College are as follows:

1. Have you heard about English autonomous learning ability? Do you study English actively or passively?

2. Do you study English on your own out of class?

3. What learning strategies do you master?

4. What may affect you in a bad way when you study English on your own?

5. Does your teacher of English introduce anything about autonomous learning?

6. Do you know how to foster English autonomous learning ability?

\section{Questionnaire Design}

The questionnaire design of English autonomous learning ability is based on the following 5 parts. Part one is the background information of the research subjects like the name, age, gender, major, their English level, etc. Part two is about the way the research subjects study English out of class and the time they spend in English study out of class. Part three is about the problems of the research subjects' motivation and English learning strategies. Part four is about the causes of those problems. Finally, part five is about whether the teachers of English guide the research subjects in out-of-class English learning or not and the research subjects' advice on fostering English autonomous learning ability.

\section{Procedures}

At first, the writer gathered 30 research subjects to do the pretest by finishing the questionnaires with a view to finding possible problems and questions that are likely to happen in the research. And then, the writer began to accomplish the formal study with the help of the teachers of English in Leshan Vocational and Technical College. All the 150 questionnaires are handed out to the research subjects who are supposed to finish the questionnaires independently, honestly and anonymously within 20 minutes.

\section{Data Collection and Data Analysis}

The writer handed out 150 questionnaires and recollected all of them, among which 145 were valid because 3 research subjects chose more than is necessary and the other 3 subjects didn't finish all of the questions. Consequently, after the confirmation of the validity of the 145 questionnaires the writer put in the data of them to the computer for further analysis with the help of SPSS16.0.

\section{MAJOR Findings OF THE RESEARCH RESUlts}

Through the analysis of the questionnaires, the writer found the students in vocational colleges who lack autonomous learning ability do have motivation problems and learning strategies problems in their English study. And the writer further analyzed the causes of those problems as follows:

1. Lack of motivation: The questionnaires show that about $79 \%$ of the research subjects agree that lack of motivation affect their autonomous learning in a big way. In most vocational colleges, English classroom is teacher-centered. The teachers decide everything for students: what to learn, when to learn, and how to learn. So, most students study passively and thus lack interest in English learning. According to the survey, $61 \%$ of the subjects think "the teacher lack passion in the classroom"; $43 \%$ of the subjects hold "the textbooks are not suitable"; $28 \%$ of the subjects are not satisfied with "the teachers" teaching approaches"; 78\% of the research subjects lack interest in "the courses"; and 53\% of the subjects attribute lack of motivation to "the teaching mode". Therefore, it is clear the students' motivation is certainly frustrated.

2. Lack of learning strategies: The questionnaires show that about $82 \%$ of the research subjects know little about learning strategies. The EFL teachers in their class seldom introduce any learning strategies to the students. Some students may have one or two kinds of method in their English study, but lacking systematic consciousness of learning strategies. In addition, compared with the study in high schools, vocational college students suffer less pressure in their 
study and they fail to adapt themselves to the change of roles, which hinder them from studying actively and spontaneously. In the high schools, the students have less spare time while in colleges they have more free time. In this case, appropriate learning strategies are more important than ever. If they lack correct learning strategies, they can not make good use of sufficient free time in colleges, thus failing to foster the good habit of autonomous learning.

3. Lack of confidence: The questionnaires show that about $65 \%$ of the research subjects lack confidence in their English study. Confidence plays a very important part in language learners' study. Most vocational college students are afraid of making mistakes when they study English. Therefore, even in the English classroom they choose to be silent when the teachers raise questions. Bad performance in the test also hinders them and discourages them. In the long run, they lose confidence in their English study. When they lose confidence, they study passively in the classroom, not to mention in their spare time. Therefore, they seldom study on their own and lack autonomous learning ability.

4. Imperfect educational system: In the United States of America, the colleges and universities follow a principle of "lenient entry, stringent exit". It is easy for American college students to enter the college but it is difficult for them to graduate. But on the other hand, Chinese educational system is known as "stringent entry, lenient exit". The students face less pressure after they enter the colleges, which make them less motivated to study autonomously. What is more, Chinese evaluation system puts more emphasis on the results of study by means of different kinds of tests and examinations, while paying less attention to the process of study, which is also one of the reasons why vocational college students lack autonomous learning ability.

\section{Suggestions of Fostering Autonomous Learning in Vocational Colleges}

1. Promoting learners' motivation: First of all, the teachers of English should fully understand the students' need, and then deliberately choose what can arouse the vocational college students' interest in the classroom so as to promote their motivation. Helping the students to change the need of society and objective requirements of the education into their own interior learning needs is one of the EFL teachers' tasks. Secondly, the teachers of English should foster the students' learning interest. The EFL teachers can adopt different ways to do the job, such as making textbook content flexible, supplementing new content beyond textbooks, assigning various kinds of tasks for students to participate in, etc. Thirdly, the teachers of English should guide the vocational college students in setting up suitable and clear goal in their study. Without clear learning goal, the students' learning is bound to be blind and passive. The EFL teachers should help the vocational college students to know themselves better so as to set up short-term goal and long-term goal as well, based on their own conditions. At first, the short-term goal should be easy to reach, so the students can be encouraged and their motivation can be promoted. Finally, the teachers of English should innovate and enrich their teaching approaches so as to arouse the vocational college students' interest. New staff is likely to attract the students' attention. The EFL teachers should try to make the students keep active attitude in their study.

2. Fostering learners' learning strategies: As is well-known, language study will be twice the result with half the effort when they students master correct learning strategies that they can use in their language study. With correct learning strategies, the students will study more actively and autonomously. Therefore, strategy training plays a vital role in the vocational college students' language study. By the way of clearly teaching vocational college students how to foster their own learning strategies in language study, the teachers of English are supposed to guide the students to learn English more effectively, and also in this way the EFL teachers can encourage the students to self-assess and self-manage their language study. Specifically, the EFL teachers can assign different kinds of language study tasks in their class. As for the students, they are supposed not only to take part in the tasks but also to explain how they fulfill the tasks and reflect on how the learning strategies help them to do the job. In the process of completing the various tasks, the EFL teachers introduce more learning strategies and the students practice those strategies and summarize what they get at the end of the process. Finally, the feed-back system should be established by which the EFL teachers can improve the learning strategy training and the teacher-student interaction is also promoted.

3. Building learners' confidence: It is believed that the learners' self-confidence is of great importance to his or her success in the language study. If the learners are short of confidence, they will feel afraid to open their mouth to speak English and also they are unwilling to take part in any tasks the EFL teachers assign to them. It is undoubted that it takes a long time for the vocational college students to establish self-confidence and the EFL teachers bear the responsibility to do the job. When the EFL teachers teach the language in their class, they are supposed to teach the vocational college students in accordance with their aptitude. Specifically, it is advisable that the EFL teachers assign easier tasks first and then go on to the more complicated ones for the vocational college students to finish. In this way, the students are easy to get success so as to build the confidence. Also, in the process of finishing the complicated tasks, the EFL teachers should encourage the students to form teams or groups, which is good for them to succeed in finishing the tasks so as to gain the confidence. Especially for timid and shy students, group-work provides a comfortable and less competitive environment for them to suffer from less pressure. And finally, the EFL teachers should adopt different criteria when they assess the students' performance, taking individual difference into account. In this way, everyone has a chance to succeed, which is good especially for those students who lack confidence and more dependent.

4. Adjusting educational system: Chinese educational system should follow the example of that of America, which is "lenient entry, stringent exit". Chinese college students should be given more pressure after they enter the colleges and universities, which can make them more motivated to study autonomously. In most vocational colleges in China, 
English is not a decider for the students' graduation. This condition should be changed into a new one in which the students can not graduate unless they reach a certain level of English. In addition, Chinese evaluation system should put more emphasis on the process of study and stress more on the students' comprehensive abilities, instead of only the results of study judged by means of different kinds of tests and examinations. Only in this way can the students become more motivated in their English study and get involved in more autonomous learning.

\section{CONCLUSION}

The study which is carried out in Leshan Vocational and Technical College by the writer in terms of the vocational college students' English autonomous leaning ability shows clearly that the teachers of English is facing a complicated and significant task of guiding the students' autonomy in their language learning. Therefore, language learners' autonomous leaning ability is supposed to be set as a goal in English teaching curriculum. The teacher-centered classroom must be altered to be student-centered. Only when the students possess more rights in their study can they become more autonomous, passionate and active. The EFL teachers should not only be the guider, but also be the innovator, facilitator, designer, reflective practitioner and companion, etc. Both the EFL teachers and the students should join hands together in promoting the students' motivation, building the learners' self-confidence as well as enriching the students' learning strategies, etc. The educational departments should also be more innovative and aggressive in reform of the educational system and evaluation system so that the quality education will prevail instead of setting test results as the only goal.

It is no doubt that developing the vocational students' English autonomous learning ability still has a long way to go. So long as the direction is correct, the goal will be attained sooner or later.

\section{REFERENCES}

[1] Awes, C. (1992). Classroom: Goals, Structure, and Student Motivation. Journal of Educational Psychology: 3, $34-36$.

[2] Ames, C. \& J. (1988). Archer Achievement Goals in the Classroom: Students' Learning Strategies and Motivation Processes. Journal of Educational Psychology, (80): 260-267.

[3] Balester V., Halasek K, and Peterson N. (1992). "Sharing Authority: Collaborative Teaching in A Computer-Based Writing Course". Computers and Composition, 9.3: 288-292

[4] Benson, P\&W. Lor. (1998). Making Sense of Autonomous Language Learning: Conception of Learning and Readiness for Autonomy. English Centre Monograph: (2): 2-8.

[5] Barson, J., Frommer, J. and Schwartz, M. (1993). "Foreign Language Learning Using E-mail in a Task Oriented Perspective: Interuniversity Experiments in Communication and Collaboration". Journal of Science Education and Technology, 2.4:565-584

[6] Benson, P \& Voller, P. (1997). Autonomy and Independence in Language Learning. London: Longman.

[7] Cotterall, S. (1995). "Readiness for Autonomy: Investigating Learner Beliefs". System, 23: 195-205.

[8] Cotterall S. (2000). "Promoting Learner Autonomy through the Curriculum: Principles for Designing Language Courses". ELT Journal 54.2: 109-117.

[9] Chen Dongchun. (2006). On the Orientation of Autonomous Learning in College English Teaching in China. Foreign Language World. (3): 32-37.

[10] Cohen, A. (1998). Strategies in Learning and Using a Second Language. London: Longman.

[11] Cook, V. (1993). Linguistics and Second Language Acquisition. London: Macmillan.

[12] Covington, M. (1992). Making the Grade: A Self-worth Perspective on Motivation and School Reform. New York: Cambridge University Press.

[13] Dam, L. (1990). Learner autonomy in practice. Ed. Lan Gathercole. London: CILT.

[14] Dickinson, L. (1992). Learner Autonomy 2: Learning Training for Language Learning. Dublin: Authentik.

[15] Dickinson, L. (1993). "Talking shop: aspects of autonomous learning. An interview with Leslie Dickinson". ELT Journal, 47.4:330-336.

[16] Dwech, C.S. \& E. L. Leggett. (1988). A Social-Cognitive Approach to Motivation and Personality. Psychological Review, (95): 256-73.

[17] Dickinson, L. (1993). Aspects of Autonomous Learning. ELT Journal, (4): 330-336.

[18] Flavell, J, H. (1976). "Metacognitive aspects of problem solving". The Nature of Intelligence. Ed. L. Resnich. Hillsdale, NJ: Lawrence Erlbaum Associates: 231-236.

[19] Gremmo M-J. (1998). "Learner autonomy: defining a new pedagogical relationship". FORUM for Modern Language Studies. University of St. Andrews: Oxford University Press: 34.

[20] Gardner, D. \& L. Miller. (1999). Establish Self-Access. Cambridge: Cambridge University Press.

[21] He Lianzhen. (2003). Cultivation of Autonomous Learning and Ability. Foreign Language Teaching and Research. (35-4): 287-289.

[22] Holec, H. (1981). Autonomy and Foreign Language Learning. Oxford: Pergamon Press.

[23] Hua Weifen. (2003). Survey on Establishing English Autonomous Learning Center. Foreign Language World. (6): 43-48.

[24] H. H. Stern. (1983). Fundamental Concepts of Language Teaching. Oxford: Oxford University Press.

[25] Holec, H. (1985). On Autonomy: Some Elementary Concepts. In P Riley (Eds.): Discourse and Learning. London: Longman.

[26] Huttunen, I. (1986). Towards Learner Autonomy in Foreign Language Learning in Senior Secondary School. Russia: University of Russia.

[27] Jiao, Lijuan. (2005). Promoting EFL Learner Autonomy. Sino-US English Teaching, (2): 27-30.

[28] Kelly, R. (1996). Language Counseling for Learner Autonomy: the Skilled Helper in Self-access Language Learning. In R. 
Pemberton, and H. D. Pemberson. (Eds.) Taking Control: Autonomy in Language Learning. Hong Kong: Hong Kong University Press. 31-54.

[29] Knowles, M. (1975). Self-directed Learning: A Guide for Learners and Teachers. New York: Association Press.

[30] Lee, I. (1998). Supporting greater in language teaching. ELT Journal, (4): 52-54.

[31] Little, D. (1991). Learner Autonomy I: Definitions, Issues and Problems. Dublin: Authentik.

[32] Li, Duan. (2005). How to Foster Learner Autonomous in English Teaching and Learning. Sino-US English Teaching, (2): $45-47$.

[33] Littlewood, W. (1996). "Autonomy: an anatomy and a framework". System, 24.4: 427-435.

[34] Li, Sihong. (2005). The Roles of the Learner, Teacher and Institution in Curriculum Development in a Chinese EFL Learning Context. Sino-US English Teaching, (2):14-18.

[35] Littlewood, W. (1999). "Defining and Developing Autonomy in East Asian Contexts". Applied Linguistics, 20 .1: 71-94.

[36] McCombs, B. L. (1989). Self-regulated Learning and Academic Achievement: a Phenomenological View. In B.J. Zimmerman \& D. H. Schunk (Eds.) Self-regulated Learning and Academic Achievement: Theory, Research, and Practice. Springer-Verlag New York Inc.: 51-82.

[37] McGarry, D. (1995). Learner Autonomy 4: The Role of Authentic Texts. Dublin: Authentic.

[38] McDevitt, B. (1997). Learner Autonomy and the Need for Learner Training. Language Learning Journal: (6):15-23.

[39] O’Malley, J. M. \& A. U. Chamot. (1990). Learning Strategies in Second Language Acquisition. Cambridge: Cambridge University Press.

[40] Peng Jinding. (2002). Study on language Learners' Autonomy in College English Teaching. Foreign Language World. (3): 15-19.

[41] Pintrich, P R. \& E. V DeGroot. (1990). Motivational and Self-Regulated Learning Components of Classroom Academic Performance. Journal of Education Psychology, (82): 33-40.

[42] Pang Weiguo. (2001). On Students' Autonomous Learning. Journal of East China Normal University. (4):25-30.

[43] Ryan, R. M. (1991).The of the Self in Autonomy and Relatedness in J. Strauss\& G R. Goethals (eds.). The Self Interdisciplinary Approaches. New York: Springer. 41-54.

[44] Scharle, A. \& A. Szabo. (2000). Learner Autonomy. Cambridge: Cambridge University Press.

[45] Sheerin, S. (1991). State of the Art: Self-access. Language Teaching, (2): 153-157.

[46] Slavin, R. E. (1996). Cooperative Learning in Middle and Secondary Schools. Clearing House, (4): 200-205.

[47] Warschauer, M. (1997). "Computer-mediated collaborative learning: Theory and practice". Modern Language Journal 3: 470-481.

[48] Wei Yuyan. (2002). Promoting Language Learners' Autonomous Learning: New Concept of Foreign Language Education. Foreign Language World. (3): 8-14.

[49] William, M. \& R. Burden. (1997). How Does the Learner Deal with the Process of Learning. Psychology for Language Teacher: (3):143-165.

[50] Wen, Q. F. (1993). Advanced Level English Learning in China: the Relationship of Modifiable Learner Variables to Learning Outcomes. Hongkong University: Unpublished Doctoral Thesis.

[51] Xie Fang. (2002). The Significance of Autonomous Learning to Foreign Language Education in Universities. Journal of Ningxia University (Humanities \& Social Sciences Edition). (1): 122-124.

[52] Zimmerman, B. J. \&M. Martinez-Pons. (1986). Development of Assessing Student Use of Self-regulated Structure Interview for Strategy. American Educational Research Journal, (23): 614-628.

[53] Zimmerman, B.J. \& M. Martinez-Pons. (1990). Student Difference in Self-regulated Learning: Relating Grade, Sex, and Giftedness to Self-efficacy and Strategy Use. Journal of Educational Psychology, (82): 51-59.

[54] Zimmerman, B.J.\&A. Bandura. (1994). Impact of Self-regulatory Influences on Writing Course Attainment. American Educational Research Journal, (31): 854-862.

Li Zou was born in Leshan City, Sichuan Province, China in 1979. He received his Master's Degree in Education Technology from Southwest University, China in 2008.

$\mathrm{He}$ is currently an associate professor in the School of Foreign Languages, Leshan Normal University, Sichuan, China. His research interests include English teaching and American literature. 